\title{
Study of feto-maternal outcome in patients of jaundice in third trimester of pregnancy
}

\author{
Brijesh J. Patel, Rajal V. Thaker*, Jagruti M. Shah, Bhavna N. Mewada
}

\begin{abstract}
Department of Obstetrics \& Gynaecology, Smt N.H.L. Municipal Medical College, Ahmedabad-380006, Gujarat,
\end{abstract} India

Received: 27 September 2015

Accepted: 02 November 2015

*Correspondence:

Dr. Rajal V Thaker,

E-mail: rajalthaker@gmail.com

Copyright: () the author(s), publisher and licensee Medip Academy. This is an open-access article distributed under the terms of the Creative Commons Attribution Non-Commercial License, which permits unrestricted non-commercial use, distribution, and reproduction in any medium, provided the original work is properly cited.

\begin{abstract}
Background: Jaundice in pregnancy is an important medical disorder, more commonly seen in developing countries than developed ones. It comprises of a formidable list of complications that may adversely affect the pregnant woman and her fetus. Objective of current study was to study causes and feto-maternal outcome in pregnancies with jaundice in $3^{\text {rd }}$ trimester.

Methods: This was a retrospective study of 49 patients admitted in department of Obstetrics \& Gynaecology at a tertiary care hospital with jaundice in 3rd trimester of pregnancy during the period from September 2008 to September 2010.

Results: Out of 9972 deliveries, 49 patients were admitted with jaundice in 3rd trimester of pregnancy. Out of them $91.1 \%$ patients delivered. Vaginal delivery occurred in $82.2 \%$ and Cesarean section done in $17.7 \%$. Preterm delivery occurred in $68.8 \%$, low birth weight (LBW) was found in $82.2 \%$, perinatal mortality occurred in $34.6 \%$ and maternal mortality occurred in $16.3 \%$ of patients.

Conclusions: Jaundice in 3rd trimester of pregnancy leads to preterm delivery, fetal distress, intra uterine fetal death (IUFD) and high perinatal \& maternal morbidity and mortality. Early diagnosis \& aggressive management at tertiary care center help in reducing maternal \& perinatal morbiditiy and mortality.
\end{abstract}

Keywords: Jaundice in pregnancy, Maternal morbidity and mortality

\section{INTRODUCTION}

Jaundice in pregnancy is an important medical disorder, more commonly seen in developing countries than developed one. It could be peculiar to pregnancy like hyperemesis gravidarum, acute fatty liver of pregnancy, cholestatic jaundice of pregnancy and jaundice complicating hypertensive disorders of pregnancy. It can be unrelated to pregnancy in patients of infective causes like viral hepatitis and malaria, gall stones, certain drugs or pregnancy in patients of chronic liver diseases. ${ }^{1}$ Jaundice in pregnancy carries a grave prognosis for both fetus and mother. It is responsible for about $60 \%$ of perinatal mortality and $14 \%$ of maternal mortality. ${ }^{2}$

The present study analysed the causes and feto-maternal outcome in pregnancies which were affected with jaundice in $3^{\text {rd }}$ trimester.

\section{METHODS}

All pregnant women with jaundice in third trimester of pregnancy who were admitted in the department of Obstetrics and Gynecology at a tertiary care hospital from September 2008 to September 2010 were studied retrospectively. After the admission necessary investigations were done and patients were treated as per diagnosis and with help of other medical specialties as and when required. The data was collected from the indoor case papers as per proforma and statistical analysis was done. 


\section{RESULTS}

During the study period 9972 deliveries occurred, out of these 49 patients were admitted with jaundice in $3^{\text {rd }}$ trimester of pregnancy.

Table 1: Demographic profile \& types of admissions.

\begin{tabular}{|ll|}
\hline \multicolumn{1}{|c}{ Age } & Number $(\%)$ \\
\hline$<20$ years & $2(4.0 \%)$ \\
\hline $20-24$ years & $25(51.0 \%)$ \\
\hline$>30$ years & $19(38.7 \%)$ \\
\hline Socio-economic status & $3(6.1 \%)$ \\
\hline Low & Number $(\%)$ \\
\hline Medium & $46(93.8 \%)$ \\
\hline High & $3(6.1 \%)$ \\
\hline Residential status & $0(\%)$ \\
\hline Urban & Number $(\%)$ \\
\hline Rural & $36(73.4 \%)$ \\
\hline Education status & $13(26.5 \%)$ \\
\hline Illiterate & Number $(\%)$ \\
\hline Primary & $13(26.5 \%)$ \\
\hline Secondary & $17(34.6 \%)$ \\
\hline Higher secondary & $12(24.4 \%)$ \\
\hline Graduate & $7(14.2 \%)$ \\
\hline Post graduate & 0 \\
\hline Emergency or Registered patients & 0 \\
\hline Emergency & Number $(\%)$ \\
\hline Registered & $32(65.3 \%)$ \\
\hline
\end{tabular}

Table 1 shows that out of all patients, $51 \%$ of patients were in age group of 20 to 24 years of age, $93.8 \%$ patients were from lower socioeconomic status and
$73.4 \%$ of patients were from urban areas. Among these patients $59 \%$ patients had either primary or secondary education and $26.5 \%$ patients were illiterate. Emergency admissions were $65.3 \%$.

Table 2 shows that, $30.5 \%$ patients had anemia, total white cell count was raised in $36.7 \%$, thrombocytopenia was found in $16.3 \%$ of patients. Test of coagulation were altered in about $30.6 \%$ of patients and $36.7 \%$ were having infected with Hepatitis E Virus (HEV).

Table 3 shows that, $44.8 \%$ patients had Infective hepatitis, out of them $36.7 \%$ had HEV infection, $6.1 \%$ had HbsAg and 2.0\% had HAV infection. Cholestatic jaundice was found in $24.4 \%$, pre-eclampsia and HELLP syndrome was found in $18.3 \%$ of patients.

Table 4 shows that, out of $91.8 \%$ patients who delivered $82.2 \%$ were delivered vaginally and $17.7 \%$ were delivered by LSCS, while $8.1 \%$ patients expired during antenatal period.

Table 5 shows that $91.8 \%$ of patients delivered, out of which $68.8 \%$ had preterm delivery and $31.1 \%$ of patients delivered at term. Live births were $91.1 \%$ and still births were $8.8 \%$.

Table 6 shows that, DIC and thrombocytopenia were the most common complication in $26.5 \%$ of patients, other complications were encephalopathy in $18.3 \%$, renal failure in $10.2 \%, \mathrm{PPH}$ in $8.1 \%$, shock in $4.0 \%$ and wound complication in $8.1 \%$ of patients. Maternal mortality occurred in $16.3 \%$. Equal number of patients died in antenatal and postnatal period.

Table 2: Results of Investigation.

\begin{tabular}{|c|c|c|c|c|c|}
\hline Investig & & $\begin{array}{c}\text { Number } \\
(\%)\end{array}$ & Inve: & yation & Number $(\%)$ \\
\hline & $<8 \mathrm{gm} / \mathrm{dl}$ & $3(6.1 \%)$ & & $<5 \mathrm{mg} / \mathrm{dl}$ & $12(24.4 \%)$ \\
\hline Hemoglobin & $8-10 \mathrm{gm} / \mathrm{dl}$ & $12(24.4 \%)$ & & $5-10 \mathrm{mg} / \mathrm{dl}$ & $18(36.7 \%)$ \\
\hline & $>10 \mathrm{gm} / \mathrm{dl}$ & $34(69.3 \%)$ & Serum Bilirubin & $10-15 \mathrm{mg} / \mathrm{dl}$ & $15(30.6 \%)$ \\
\hline & Raised & $18(36.7 \%)$ & & $15-20 \mathrm{mg} / \mathrm{dl}$ & $4(8.1 \%)$ \\
\hline Total WBC count & Normal & $31(63.2 \%)$ & & $<100 \mathrm{U} / \mathrm{L}$ & $12(24.4 \%)$ \\
\hline & $<1 \mathrm{lac} / \mathrm{cu} \mathrm{mm}$ & $8(16.3 \%)$ & SGPT & 100-1000U/L & $33(67.3 \%)$ \\
\hline Platelet count & $>11 \mathrm{lac} / \mathrm{cu} \mathrm{mm}$ & $41(83.6 \%)$ & & $>1000 \mathrm{U} / \mathrm{L}$ & $4(8.1 \%)$ \\
\hline & Prolonged & $3(6.1 \%)$ & Serum alkaline & Raised & $23(46.9 \%)$ \\
\hline Bleeding time & Normal & $46(93.8 \%)$ & phosphatase & Normal & $26(53.0 \%)$ \\
\hline Clottingtim & Prolonged & $3(6.1 \%)$ & Viral & arkers & Number (\%) \\
\hline Clotting time & Normal & $46(93.8 \%)$ & Hepatitis B posit & & $3(6.1 \%)$ \\
\hline Prothrombine time & Prolonged & $15(30.6 \%)$ & Hepatitis A posit & & $1(2.0 \%)$ \\
\hline Protnrombine time & Normal & $34(69.3 \%)$ & Hepatitis E positi & & $18(36.7 \%)$ \\
\hline Activated partial & Prolonged & $15(30.6 \%)$ & Hepatitis C posit & & 0 \\
\hline thromboplastine time & Normal & $34(69.3 \%)$ & & & \\
\hline
\end{tabular}


Table 3: Causes of jaundice in $3^{\text {rd }}$ trimester of pregnancy.

\begin{tabular}{|c|c|c|c|c|}
\hline \multicolumn{3}{|c|}{ Cause } & Number & $\begin{array}{c}\% \text { of } \\
\text { patients }\end{array}$ \\
\hline \multirow{4}{*}{\multicolumn{2}{|c|}{ Infective Hepatitis }} & A & 1 & 2.0 \\
\hline & & B & 3 & 6.1 \\
\hline & & $\mathrm{C}$ & 0 & 0 \\
\hline & & $\mathrm{E}$ & 18 & 36.7 \\
\hline \multicolumn{3}{|c|}{ Cholestatic jaundice of pregnancy } & 11 & 22.4 \\
\hline \multicolumn{3}{|c|}{ Pre-eclampsia+HELLP Syndrome } & 9 & 18.3 \\
\hline \multicolumn{3}{|c|}{$\begin{array}{l}\text { Hemolytic } \\
\text { jaundice }\end{array}$} & 5 & 10.2 \\
\hline \multirow[t]{2}{*}{ Others } & Septi & & 1 & 2.0 \\
\hline & gall s & & 1 & 2.0 \\
\hline
\end{tabular}

Table 4: Outcome of pregnancy.

\begin{tabular}{|c|c|c|c|}
\hline \multicolumn{2}{|c|}{ Outcome } & Number & $\%$ of \\
\hline \multirow{2}{*}{$\begin{array}{l}\text { Delivered } \\
45(91.8 \%)\end{array}$} & Vaginal delivery & 37 & 82.2 \\
\hline & LSCS & 8 & 17.1 \\
\hline Undelivered & Expired & 4 & 8.1 \\
\hline
\end{tabular}

Table 5: Outcome of baby.

\begin{tabular}{|c|c|c|c|c|}
\hline & \multicolumn{2}{|l|}{ Outcome } & Number & $\begin{array}{c}\% \text { of } \\
\text { patients }\end{array}$ \\
\hline \multirow{7}{*}{$\begin{array}{l}\text { Preterm } \\
\text { Delivery } \\
31(68.8 \%)\end{array}$} & \multicolumn{2}{|l|}{ Live Birth } & 28 & 90.3 \\
\hline & \multicolumn{2}{|l|}{ Still Birth } & 3 & 9.6 \\
\hline & \multirow{2}{*}{ Meconium } & Yes & 10 & 32.2 \\
\hline & & No & 21 & 67.7 \\
\hline & \multirow{2}{*}{ Weight } & $>2.5 \mathrm{~kg}$ & 4 & 12.9 \\
\hline & & $<2.5 \mathrm{~kg}$ & 27 & 87.0 \\
\hline & \multicolumn{2}{|c|}{ Admission in NICU } & 17 & 54.8 \\
\hline \multirow{7}{*}{$\begin{array}{l}\text { Fullterm } \\
\text { Delivery } \\
14(31.1 \%)\end{array}$} & \multicolumn{2}{|l|}{ Live Birth } & 13 & 92.8 \\
\hline & \multicolumn{2}{|l|}{ Still Birth } & 1 & 7.1 \\
\hline & \multirow{2}{*}{ Meconium } & Yes & 7 & 50 \\
\hline & & No & 7 & 50 \\
\hline & \multirow{2}{*}{ Weight } & $>2.5 \mathrm{~kg}$ & 4 & 28.5 \\
\hline & & $<2.5 \mathrm{~kg}$ & 10 & 71.4 \\
\hline & \multicolumn{2}{|c|}{ Admission in NICU } & 4 & 28.5 \\
\hline \multicolumn{3}{|c|}{ Undelivered expired } & 4 & 8.1 \\
\hline
\end{tabular}

\section{DISCUSSION}

During the study period total 9972 deliveries occurred, out of these 49 patients were admitted with jaundice in $3^{\text {rd }}$ trimester of pregnancy. The proportion of jaundice in our study was $0.4 \%$. Studies conducted by Tripti et al, ${ }^{2}$ Oladokun $\mathrm{A}$ et $\mathrm{al}^{3}$ and Parveen $\mathrm{T}$ et $\mathrm{al}^{4}$ have reported incidence of jaundice $0.5 \%, 0.3 \%$ and $1.3 \%$ respectively.

In present study, $65.3 \%$ of patients were emergency admission. Study conducted by Tripti et al had $80.5 \%$ of emergency admissions. ${ }^{2}$
Table 6: Maternal morbidity and mortality*.

\begin{tabular}{|c|c|c|c|}
\hline \multicolumn{2}{|c|}{ Complication } & Number & $\begin{array}{c}\% \text { of } \\
\text { patients }\end{array}$ \\
\hline \multirow{6}{*}{ Morbidity } & $\begin{array}{l}\text { DIC and } \\
\text { Thrombocytopenia }\end{array}$ & 13 & 26.5 \\
\hline & Encephalopathy & 9 & 18.3 \\
\hline & Renal failure & 5 & 10.2 \\
\hline & $\begin{array}{l}\text { Post partum } \\
\text { haemorrhage }\end{array}$ & 4 & 8.1 \\
\hline & $\begin{array}{l}\text { Wound } \\
\text { complication }\end{array}$ & 4 & 8.1 \\
\hline & Shock & 2 & 4.0 \\
\hline \multirow[t]{2}{*}{ Mortality } & Antenatal & $\begin{array}{l}4 \\
4\end{array}$ & 8.1 \\
\hline & post natal & & 8.1 \\
\hline
\end{tabular}

*More than one complication was present in each patient.

In present study, infective hepatitis was present in $44.8 \%$ of patients. Studies conducted by Oladokun $\mathrm{A}$ et $\mathrm{al}^{3}$ and Yeul et $\mathrm{al}^{5}$ have reported $58.3 \%$ and $61.5 \%$ of infective hepatitis respectively. In present study, $36.7 \%$ patients had HEV infection. Safary et al, ${ }^{6}$ Yeul et $\mathrm{al}^{5}$ and Kumar et $\mathrm{al}^{7}$ have reported $35-50 \%$ incidence of $\mathrm{HEV}$.

In present study, $91.8 \%$ patient delivered. Out of these $82.2 \%$ were delivered vaginally while $17.7 \%$ were delivered by LSCS. Tripti et $\mathrm{al}^{2}$ have reported vaginal delivery in $58 \%$ and cesarean section was done in $28 \%$.

In present study, out of $91.8 \%$ of patients who delivered, $68.8 \%$ had preterm delivery and $31.1 \%$ of patients delivered at term. Study by Oladokun $\mathrm{A}$ et $\mathrm{al}^{3}$ and Parveen $\mathrm{T}$ et $\mathrm{al}^{4}$ have reported $39.6 \%$ and $71.1 \%$ of preterm deliveries respectively. In our study, liquor was meconiun stained in $37.7 \%$. In a study by Ray et $\mathrm{al}^{8}$ liquor was meconium stained in $45 \%$. In present study, LBW was found in $82.2 \%$ of babies. Parveen T et $\mathrm{al}^{4}$ have reported $55.8 \%$ of LBW babies. In present study, IUFD was present in $8.8 \%$. Oladokun $\mathrm{A}$ et $\mathrm{al}^{3}$ have reported $8.3 \%$ of IUFD. In present study, perinatal mortality was $34.6 \%$. Tripti et $\mathrm{al}^{2}$ and Rathi et $\mathrm{al}^{9}$ have reported perinatal mortality of $61.7 \%$ and $35.4 \%$ respectively. Good NICU helps in reduction of perinatal mortality.

In present study, DIC and thrombocytopenia were the most common complications found in $26.5 \%$ of patients. Encephalopathy, renal failure, PPH and shock found in $18.3 \%, 10.2 \%, 8.1 \%$ and $4.0 \%$ respectively. Tripti et $\mathrm{al}^{2}$ have reported DIC and thrombocytopenia, encephalopathy, renal failure, PPH and shock in $21 \%$, $26 \%, 19 \%, 4.8 \%$ and $4.8 \%$ respectively. Parveen $\mathrm{T}$ et $\mathrm{al}^{4}$ have reported encephalopathy and $\mathrm{PPH}$ in $10.8 \%$ and $15.3 \%$ of patients respectively.

Blood components were given in $59.1 \%$ of patients. Packed cell volume, fresh frozen plasma, platelet reached component and cryoprecipitate were given in $28.5 \%$, $48.9 \%, 18.3 \%$ and $8.1 \%$ of the patients respectively. 
Availability of blood components has helped in reducing maternal mortality and morbidity in patients of pregnancy with jaundice.

In present study, out of 8 maternal deaths, $8.1 \%$ of patients expired undelivered and $8.1 \%$ expired after delivery. In a study by Tripti et al, $4.8 \%$ of patients expired undelivered and $19.5 \%$ patients expired after delivery. $^{2}$

In present study, when initial serum bilirubin was $<10$ $\mathrm{mg} \%, 10-15 \mathrm{mg} \%$ and $15-20 \mathrm{mg} \%$, maternal mortality was $9.6 \%, 21.4 \%$ and $50 \%$ respectively. Tripti et al have reported $8.3 \%, 22.2 \%$ and $71.4 \%$ of maternal mortality with similar range of bilirubin concentrations. ${ }^{2}$ Higher bilirubin levels are associated with high maternal mortality.

In present study, maternal mortality occurred in $16.3 \%$ of patients. Out of these 7 patients had DIC, 5 patients had hepatic encephalopathy, 7 patients ARF, 2 patients had ARDS and shock and 1 patient had pulmonary embolism. More than one complication was found in each patient. Trivedi et al, ${ }^{10}$ Tripti et $\mathrm{al}^{2}$ and Parveen $\mathrm{T}$ et $\mathrm{al}^{4}$ have reported $29.3 \%, 24.3 \%$ and $8.6 \%$ of maternal mortality respectively. Early diagnosis and aggressive management of pregnancy with jaundice at tertiary care centre and good NICU helps in reducing maternal and perinatal mortality and morbidity.

\section{CONCLUSIONS}

Jaundice in third trimester of pregnancy is a bad combination. There was a higher risk of preterm delivery, fetal distress, IUFD and meconium aspiration leading to high perinatal mortality and morbidity. Infective Hepatitis due to HEV had a grave prognosis with high maternal mortality. Higher bilirubin levels were associated with high maternal mortality. Public health education help in creating awareness regarding different mode of transmission of hepatitis and routine antenatal screening for hepatitis B virus is advocated, thereby reducing the incidence of jaundice in pregnancy due to hepatitis. Availability of blood components has greatly revolutionized the management of jaundice. Early diagnosis and aggressive management of pregnancy with jaundice at tertiary care centre and good NICU helps in reducing maternal and perinatal mortality and morbidity.

\section{Funding: No funding sources}

Conflict of interest: None declared

Ethical approval: The study was approved by the Institutional Ethics Committee

\section{REFERENCES}

1. Hay J, Eileen. Liver disease in pregnancy. Hepatology. 2008;47(3):1067-76.

2. Nagaria Tripti, Agrwal Sarita. Fetomaternal outcome in Jaundice during Pregnancy. J Obstet Gynecol India. 2005;55:424-7.

3. Oladokun A, Otegbayo JA, Adeniyi AA. Maternal \& fetal outcome of Jaundice in pregnancy at university college Hospital, Ibadan. Niger J Clin Pract. 2009;12(3):277-80.

4. Parveen T, Begum F, Akhtar N. Feto-maternal outcome of jaundice in pregnancy at tertiary care hospital. Mymensingh Med J. 2015;24(3):528-36.

5. Yeul Veronica Irene, Kaur Vaneeta. HEV in pregnancy. J Obstet Gynecol. India. 2006;56:146-8.

6. Safary A. Perspectives of vaccination against hepatitis E. Intervirology. 2001;44:162-3.

7. Kumar A, Beniwal B, Kar P. Hepatitis $E$ in pregnancy. Obstetric Gynecol Surv. 2005;60:7-8.

8. Ray Alokananda, Tata Rashne J, Balsara. Cholestasis of pregnancy. J of Gynecol India. 2005;55:247-50.

9. U Rathi, Bapat, M Rathi, Abraham Effect of liver disease on maternal and fetal outcome - a prospective study. Indian J Gastroenterol. 2007;26(2):59-63.

10. Trivedi SS, Goyal U, Gupta U. A study of maternal mortality due to viral hepatitis. J Obstet Gynecol India. 2003;53:551-3.

Cite this article as: Patel BJ, Thaker RV, Shah JM, Mewada BN. Study of feto-maternal outcome in patients of jaundice in third trimester of pregnancy. Int J Reprod Contracept Obstet Gynecol 2015;4:1961-4. 